\title{
Timo Järvilehto
}

\section{Psyykkinen toiminta ja aivopuoliskojen tehtävät}

\begin{abstract}
Järvilehto, Timo. 1984. Psyyken toiminta ja aivopuoliskojen tehtävät. Aikuiskasvatus 4, 1, 15-21. - Artikkelissa tarkastellaan aivopuoliskojen toimintoja ja aivotoiminnan ja psyyken välisiä yhteyksiä. Erityisesti keskitytään aivotoiminnan asymmentrian tutkimuksen esittelyyn ja virheelliseen tutkimustulosten yksinkertaistamiseen. Artikkeliin liittyy erillinen esipuhe.
\end{abstract}

Vaikka aivoja yleensä pidetään yhtenä elimenä, ne itse asiassa muodostuvat useista symmetrisistä osista, joista silmäänpistävimmät osat ovat aivopuoliskot, hemisfäärit. Nämä aivojen osat ovat tiukkaan yhteen pakatut kal- lon sisään, mutta ne erottaa toisistaan syvä uurre, jonka yli kulkee valtaisa joukko aivopuoliskoja yhdistäviä hermoratoja, commissuuria. Suurin niistä on corpus callosum, aivokurkiainen. Nämä hermoradat muodostavat

\section{Ihmiskuvan tieteellisistä perusteista}

Suomalaiset aikuiskasvattajat kävivät viime vuonna keskustelua siitä, millaisen ihmiskäsityksen varaan aikuiskasvatustyön kehittämissuunnitelmat tulisi rakentaa. Tässä keskustelussa perusteita ei etsitty neurofysiologiasta. Samoihin aikoihin maahamme levisi kuitenkin amerikkalaisen Richard Sperryn saaman Nobelin palkinnon virittämä uudenlainen tapa tarkastella ihmisen psyykkeä. Jo aiemmin muodikkaaksi käynyttä luovuuden, spontanismin ja "pehmeiden arvojen" korostusta järjen pakkovaltaa vastaan alettiin perustella neurofysiologisilla tutkimustuloksilla. Länsimaista ihmistä vaivaa, niin sanotaan, kylmää rationaalisuutta edustavan vasemman aivopuoliskon ylivalta. Luovuutta ja inhimillisyyttä edustavaa oikeaa aivopuoliskoa käytetään liian vähän. Aivofysiologiset perustelut tuntuivat antavan mitä hurjimmille ihmisen psyykkeä ja yhteiskunnallista toimintaa koskeville väitteille tieteellisen leiman.

On selvää, että aikuiskasvattajienkin ihmiskuvan tulee perustua ihmistä koskevaan tieteelliseen tietoon. Oikea ja totuudenmukainen käsitys ihmisestä ei kuitenkaan synny tekemällä yksittäistä tutkimustuloksista laajoja päätelmiä, niin mielikuvitusta kiehtovaa kuin se saattaa ollakin. Se, mitä näin syntyy, ei ole pätevää uutta tietoa, vaan vanhojen käsitysten ja ennakkoluulojen lämmittelyä. Oikean käsityksen muodostaminen vaatii perusteellisuutta, kriittisyyttä ja kaiken itsestäänselvän koettelua.

Jatkaakseen ja syventääkseen ihmiskuvasta käytävää keskustelua Aikuiskasvatus -lehti on pyytänyt neuropsykologian tutkijalta, tri Timo Järvilehdolta artikkelin psyykkisestä toiminnasta ja aivopuoliskojen tehtävistä. Artikkelissa eritellään ensin aivopuoliskojen toiminnallista erilaisuutta koskevista tutkimuksista tehtyjen päätelmien tieteellistä oikeutusta ja arvioidaan sen jälkeen näiden tutkimusten taustalla olevaa ihmiskäsitystä. Aikuiskasvatuksen kannalta artikkelille antaa erityistä ajankohtaisuutta se, että sama mekanistinen tapa tarkastella ihmistä passiivisena, tietokoneen tavoin tietoa käsittelevänä "makroprosessorina" joka on ominainen aivopuoliskojen toiminnallista erikoistumista koskeville tutkimuksille tulee yhä useammin esiin myös aikuisten oppimista ja opettamista koskevissa ns. kognitivistisissa tarkasteluissa (Katso esim. Psykologia lehden numeroissa $3 \mathrm{ja}$ 5/83 käyty keskustelu kognitiivisesta psykologiasta ja opetuksesta).

Jaakko Virkkunen 
ainoan suhteellisen suoran yhteyden aivopuoliskojen välille; muita yhteyksiä on kylläkin olemassa syvemmällä sijaitsevien rakenteiden kautta.

Jo 1800-luvulla saatiin selville, että aivopuoliskot ovat ikäänkuin toistensa peilikuvia ja kummankin kuorialueilla sijaitsee paikkoja, joita sähköisesti ärsyttämällä voitiin tuottaa kehon vastakkaisen puolen lihasten liikkeitä. Samoin voitiin todeta, että useat aivopuoliskoihin tulevat aistien hermoradat risteytyvät siten, että ne kytkeytyvät pääosin kehon vastakkaiselle puolelle. Tämä risteytyminen ei kuitenkaan ole täydellistä.

Aivopuoliskojen samankaltaisuus ja se seik$\mathrm{ka}$, että psyykkisten toimintojen katsottiin sijaitsevan aivokuoren eri osissa, herättivät jo 1800-luvulla kysymyksen siitä oliko ihmisellä itse asiassa kaksi psyykeä. Tällä kannalla oli muun muassa Wigan (1844) ja kuuluisa psykofyysikko Fechnerkin oletti, että ihmiselle syntyisi kaksi sielua, jos olisi mahdollista erottaa aivopuoliskot toisistaan. Fechner kirjoittaa muun muassa:

"'Vaikka molemmat aivouolisikot aloittavatkin varustettuina samoilla mielialoilla, kyvyillä, tiedoilla ja muistoilla, todellakin yleisesti samalla tajunnalla; (aivopuoliskojen erottamisen jälkeen) kumpikin kehittyy eri tavoin niiden ulkoisten suhteiden mukaisesti, joihin kumpikin joutuu." (Zangwillin, 1976, mukaan)

Kuten myöhemmin todetaan, Fechner jakaa käsityksensä useiden nykyaikaisten tutkijoiden kanssa.

Fechnerin näkemys ei kuitenkaan jäänyt vaille vastustajia. Esimerkiksi McDougall, englantilainen psykologi, vastusti voimakkaasti käsitystä, että tajunnan tai tietoisuuden yhtenäisyys olisi sidottu hermokudoksen yhtenäisyyteen. Hän jopa meni niin pitkälle, että esitti Sir Charles Sherringtonille pyynnön, että tämä leikkaisi hänen aivopuoliskojansa yhdistävät radat, mikäli häntä sattuisł kohtaamaan parantumaton tauti. Tätä kautta hän ajatteli kykenevänsä osoittamaan, että hänen tajuntansa säilyisi yhtenä huolimatta kahden aivopuoliskon olemassaolosta.

Leikkausta ei koskaan suoritettu; sen sijaan sama leikkaus on viime vuosikymmenien aikana toteutettu vaikeasti epilepsiasta kärsiville potilaille. Ja kuten tulemme näkemään leikkausten tulosten tulkinta on johtanut valtaisaan aivopuoliskojen toimintoja käsittelevien tutkimusten aaltoon.

Vähän 1800-luvun puolivälin jälkeen ranskalainen Paul Broca teki löydöksen, jolla tuli olemaan kantavuutta aina meidän päiviimme saakka. Broca totesi, että potilailla, joiden pu- hekyky oli aivovaurion johdosta häiriintynyt, vamma sijaitsi aina samalla puolella aivoja, hieman vasemman ohimolohkon edessä. Broca nimesi häiriön afemiaksi (myöhemmin afasia) ja väitti puheen kontrollin tapahtuvan tämän alueen avulla, tarkemmin sanoen: että puhekyky sijaitsisi tällä alueella, jota myöhemmin ryhdyttiin nimittämään Brocan alueeksi. Brocasta tuli ensimmäinen varteenotettava psyykkisten toimintojen lokalisaatioteorian puolustaja.

Brocan löydös on vahvistettu monin kerroin tällä vuosisadalla ja huolimatta siitä, että psyykkisten toimintojen lokalisointi aivoihin on saanut vastansa vahvaa kritiikkiä, löydös lienee varmin viite siihen suuntaan, että aivoissa on aivan tietty rakenne, joka vastaa puhetoiminnoista.

Tosin viime vuosien tutkimus on huomattavasti monimutkaistanut tilannetta, sillä on todettu, että kaikilla ihmisillä tämä alue ei sijaitse vasemmassa aivopuoliskossa, vaan se saattaa olla oikeassa tai edustettuna molemmissa aivopuoliskoissa. Kuitenkin ihmisten enemmistön osalta Brocan löydös näyttäisi pitävän paikkansa. Merkitseekö tämä sitten todella sitä, että puhekyky voisi sijaita aivopuoliskossa ja että ylipäänsä on mielekästä puhua aivopuoliskojen psyykkisistä toiminnoista?

Ennenkuin tarkastelen tätä kysymystä, esittelen hiemen viimeaikaista kehitystä tutkimuksessa, jonka päämääränä on ollut löytää aivopuoliskojen toiminnallisia eroja. Puoliskothan ovat suhteellisen symmetrisiä; Brocan löydös viittaisi kuitenkin siihen, että huolimatta anatomisesta samankaltaisuudesta puoliskoilla voisi olla toiminnallisia eroja, toiminnallista asymmetriaa, kuten nykyaikainen termi kuuluu.

\section{Aivopuoliskojen erottamisen seuraukset}

Aivopuoliskoja yhdistää siis pääosin valtaisa, pari sataa miljoonaa hermosäiettä käsittävä hermokimppu, corpus callosum. Tämän lisäksi aivopuoliskojen välillä on joitakin pienempiä yhteyksiä (anterioiriset ja prosterioiriset commissuurat). 1940-luvun alkupuolella tuli neurokirurgien mieleen, että puoliskojan yhdistävien hermoratojen katkaisu saattaisi helpottaa vaikeita kaatumatautikohtauksia, joissa keskeisenä tekijänä näytti olevan aivojen häiriötoiminnan leviäminen aivopuoliskosta toiseen.

Leikkauksilla ei kuitenkaan näyttänyt olevan juuri vaikutusta sen enempää epilepsian 
hoidossa kuin potilaiden toiminnan kannalta. Potilas, jonka commissuurat oli osittain tuhottu (yleensä katkaisua ei suoritettu täydellisesti), ei muuttunut huomattavasti käyttäytymiseltään. Tässä vaiheessa leikkaukset lopetettiin ja tehtiin johtopäätös, että commissuurilla ei ollut toiminnallista merkitystä.

Kymmenisen vuotta myöhemmin kuva alkoi kuitenkin muuttua. Philip Vogel ja Joseph Bogen, kaksi amerikkalaista neurokirurgia, tulivat ajatelleeksi, että leikkaukset eivät ehkä olleet menestyksellisiä siksi, että aivopuoliskoja ei oltu eristetty täysin toisistaan. Koska toisaalta eläinkokeiden avulla oli todettu, että eläin ei tällaisen operaation jälkeen näyttänyt erityisen häiriintyneeltä, kirurgit uskaltautuivat suorittamaan täydellisen leikkauksen (commissurotomian) vaikeille epilepsiapotilaille.

Tulokset olivat melko tyydyttäviä. Potilaan kohtaukset heikkenivät ja potilas näytti muuten olevan entisellään. Kuitenkin Michael Gazzanigan ja Roger Sperryn (joka vuonna 1981 sai tutkimuksistaan Nobel-palkinnon) huolelliset tutkimukset osoittivat, että jotain kuitenkin oli vialla potilaassa.

Tyypillinen tutkimustilanne oli esimerkiksi seuraavanlainen: Potilas asetettiin istumaan kankaan eteen, jossa sijaitsi musta risti ja häntä kehotettiin tuijottamaan ristiä. Ristin molemmille puolille projisoitiin lyhyesti sanat, jotka muodostivat yhdyssanan (esimerkiksi tee - kuppi). Kun potilaalta kysyttiin, minkä sanan hän oli nähnyt, hän mainitsi ristin oikelle puolelle esitetyn sanan (siis kuppi). Kuitenkin, jos häntä pyydettiin näyttämään vasemmalla kädellään sanajoukosta, minkä sanan hän oli nähnyt, hän osoitti sanaa 'tee', huolimatta siitä, että myös 'tee-kuppi"' oli löydettävissä sanojen joukosta. Näytti siis siltä, että potilas ei ollut lainkaan nähnyt yhdyssanaa, vaan pelkästään erilliset sanat "tee"' ja "kuppi"'. Toiseen sanaan hän pystyi viittamaan käyttämällä vasenta kättään, toisen hän ilmoitti pyydettäessä häntä mainitsemaan sana.

Useiden samantyyppisten tutkimustulosten pohjalta Sperry ja työtoverinsa (1969) laativat mallin, jonka he katsoivat selittävän tutkimustuloksen. Koska vasemmasta näkökentästä on hermostollisia yhteyksiä pääasiassa oikeaan aivopuoliskoon ja oikean näkökentän osalta on päinvastoin, tutkijat ajattelivat kummankin aivopuoliskon vastaanottavan eri sanan ilman, että aivpuoliskojen välillä oli kommunikaatiota. Koska oikealla olevan sanan ajateltiin "'menevän" vasempaan aivopuoliskoon (siis siihen, jossa puhekeskuksen katsotaan sijaitsevan), koehenkilö mainitsi tämän sanan silloin kun häntä pyydettiin puhumaan. Toisaalta vasemmalla oleva sana "meni" oikeaan aivopuoliskoon, jossa oletettavasti puhekeskusta ei ollut, potilas ei siten voinut sanoa tätä sanaa, mutta kykeni sen kuitenkin vasemmalla kädellään näyttämään. Näin siksi, että vasemman käden ohjauksen katsotaan tapahtuvan lähinnä oikeasta aivopuoliskosta.

Kumpikin aivopuolisko näytti siis olevan tajuinen ja tietoinen ympäristöstään, mutta erillisenä, riippumattomana toisesta aivopuoliskosta. Siten potilaalle näytti itse asiassa olevan kaksi eri persoonallisuutta päänsä sisällä, johtopäätös, jonka - kuten huomasimme Fechner oli ennustanut jo yli sata vuotta sitten.

Alkuperäiset tutkimukset johtivat sarjaan lisätutkimuksia, joilla pyritään osoittamaan, että potilaiden aivopuoliskojen psyykkiset ',ominaisuudet" olivat toisilleen varsin vastakkaisia. Sperry kirjoittaa mm., että vasen aivopuolisko, jonka siis ajatellaan johtavan puhetta, olisi aggressiivisempi, toimeenpanevampi ja johtavampi useiden käyttäytymismuotojen säätelyssä, kun taas "mykkä"' oikea aivopuolisko olisi passiivisempi, "'aivojen hiljainen matkustaja", joka kuitenkin kykenisi esimerkiksi taiteelliseen toimintaan paremmin kuin sen kylmästi ajatteleva, tiukan looginen kumppani (Sperry, 1976).

\section{Aivojen toiminnallinen "asymmetria",}

Potilailta saadut tulokset viittasivat siis siihen, että aivopuoliskojen välillä on todella toiminnallisia eroja, jopa täysin vastakkaisiakin, ja aivotoiminnan asymmetrian tutkimus sai nyt uuden suunnan: Potilaista siirryttiin normaalien koehenkilöiden tutkimukseen. Kuusikymmenluvun alusta lähtien asymmetria-tutkimuksia on kertynyt niin valtaisa määrä, että niiden perinpohjainen käsittely on mahdotonta näissä puitteissa. Lukija voi saada tutkimuksesta perusteellisemman käsityksen tutustumalla esimerkiksi Springerin ja Deutschin teokseen "Left brain, right brain"' (1981). Kuitenkin voidaan todeta, että asymmetria-tutkimukset näyttävät yleisesti vahvistavan käsitystä, että aivopuoliskojen välillä on varsin monimutkaisia toiminnallisia eroja.

Asymmetria-tutkimukset etenevät yleensä seuraavalla tavalla: Valitaan jotakin ärsykemateriaalia esimerkiksi sanoja tai lyhyitä musiikin katkelmia ja esitetään niitä koehenkilön korviin, sanat esimerkiksi oikeaan korvaan ja musiikki vasempaan. Tämän jälkeen katsotaan, kuinka monta sanaa tai musiikkikatkel- 
maa koehenkilö kykenee tunnistamaan taustakohinasta. Esitysmateriaali vaihdetaan korvasta toiseen ja sitten uudistetaan tunnistustehtävä. Jos asymmetriaa ei ole, tehtävä sujuu kummassakin tapauksessa yhtä hyvin; asymmetriaa taas esiintyy, jos jommalla kummalla puolella ärsykemateriaalin tunnistaminen sujuu paremmin kuin toisella puolella.

Usein tämäntyyppisen kokeen lopputulos on ollut se, että oikeaan korvaan esitetyt sanat tunnistetaan helpommin kuin vasempaan esitetyt; musiikin osalta tilanne on taas päinvastainen. Ja tutkijan johtopäätös on selvä: Syy on siinä, että oikeasta korvasta tieto välittyy vasempaan, "verbaaliseen" aivopuoliskoon, kun taas vasemmasta korvasta päästään helpommin oikeaan, "musikaaliseen" aivopuoliskoon. Samantyyppisiä kokeita on suoritettu kaikkien aistipiirien kohdalla (makua ja hajua lukuunottamatta).

Yhdellä henkilöllä todettu aivopuoliskojen toiminnallinen asymmetria johti nopeasti myös eri ihmisryhmien toiminnallisen asymmetrian vertailuun. Olihan jo aikaisemmin selvinnyt, että "'puhekeskus" ei kaikilla ihmisillä sijaitse vasemmassa aivopuoliskossa. Tähän liittyi myös sen seikan toteaminen, että kaikki ihmiset eivät ole oikeakätisiä, joidenkin ihmisten kohdalla saattaisi siis oikea aivopuolisko ollakin "johtavammassa" asemassa kuin vasen. Kätisyys on yleensä liitetty siihen, kumpi aivopuolisko toimii johtavassa asemassa; oikeakätisillä vasen ja vasenkätisillä oikea. Tosin varsin suurella osalla vasenkätisiä vasen aivopuolisko näyttäisi kuitenkin olevan johtavassa asemassa.

Yksilöiden välisiä eroja selvittelevässä asymmetria- tutkimuksessa on käytetty mitä erilaisempia ihmisryhmiä ja tulokset ovat olleet varsin vaihtelevia. Naisten kohdalla asymmetriaa on väitetty olevan vähemmän kuin miesten, lasten kohdalla vähemmän kuin aikuisten, vasenkätisten kohdalla vähemmän kuin oikeakätisten. Aivopuoliskojen välisiä toiminnallisia eroja on pyritty kytkemään väkivaltarikollisuuden synnyn selityksiin; on myös esitetty, että läntisen ja itämaisen ihmisen välinen ajattelutapojen ero johtuisi siitä, että itämainen ihminen käyttää enemmän oikeaa aivopuoliskoaan kuin länsimäinen. Onpa jopa ehdotettu, että itsepetoksen hermostollinen perusta olisi juuri siinä, että ihmisellä on kaksi aivopuoliskoa, jotka kilpailevat keskenään.

Esimerkkinä tällaisista äärimmilleen viedyistä yksinkertaistuksista mainittakoon erään amerikkalaisen tutkijaryhmän esittämä "teo- ria", jonka mukaan Hitlerin poliittinen ideologia ja toiminta selittyisi sillä, että hänen toimintansa ohjauksessa oikealla aivopuoliskolla olisi ollut keskeisempi asema kuin vasemmalla aivopuoliskolla.

Jotta lukija saisi selkeän käsityksen siitä, kuinka pitkälle tämäntyyppinen pohdiskelu saattaa mennä, lainaan lyhyen osan artikkelista, joka on julkaistu sinänsä arvostetussa kansainvälisessä lehdessä "Confinia Psychiatrica":

"'.. Hitlerin halulle hyökätä sekä länteen että itään voidaan antaa neurologisia selityksiä. Lännessä Hitleriä kiinnosti erityisesti Ranskan valtaus... Hänen hyökkäystään länteen voidaan pitää symbolisena yrityksenä tuhota vasen aivopuolisko... sillä Ranska on traditionaalisesti symboloinut rationaalisuutta, järjestystä ja selkeyttä. Hitler, irrationaalisuuden mestari, yritti tuhota tuollaisen keskuksen aivan samoin kuin hän yritti tuhota juutalaiset... Hitlerin hyökkäys itään oli yritys palautua kokonaisvaltaiseen, eriytymättömään mystiseen tilaan. Tämä on... samaa kuin sanoa, että Hitler hyökkäsi itään, koska se edusti hänelle tilaa, jossa oikea aivopuolisko oli täysinkontrollissa." (Martindale ym., 1976, käännös T.J.)

\section{Tutkimuksen perusoletusten kritiikki}

Kun yllä selostetusta, sinänsä asiallisentuntuisesta tutkimuksesta voidaan johtua ylläolevan esimerkin kaltaisille linjoille, herää kysymys, onko koko tutkimuslinjan perusteissa sittenkin jotain vialla.

Koska aivopuoliskot ovat tavallaan toistensa peilikuvia, tutkijoita on houkuttanut aivopuoliskojen psyykkisten "ominaisuuksien" vastakkainasettelu. Vasemman aivopuoliskon esitetään olevan verbaalinen, analyyttinen, rationaalinen, looginen, prosessoivan informaatiota sarjallisesti ja reagoivan erityisesti samanlaisuuteen. Oikealle puoliskolle olisi taas tyypillistä ei-verbaalisen materiaalin, kuten musiikin käsittely, kokonaisvaltaisuus, emotionaalisuus, informaation rinnakkainen prosessointi ja erityisesti erilaisuuksien tuottaminen.

Mutta voidaanko hermomassalle todella antaa tällaisia ominaisuuksia? Tavallisesti olemme tottuneet lukemaan tuollaisia ominaisuuksia kokonaisen ihmisen, henkilön ominaisuuksiksi. Voivatko siis hermosolut olla esimerkiksi "emotionaalisia" tai "aggressiivisia"?

Aivan varmasti eivät voi! Leikillisesti voitaisiin kai sanoa, että esimerkiksi aggressiiviset hermosolut olisivat vaaraksi lähinnä muille aivojen hermosoluille, ei ihmisen lähiympäristölle. 
Seuraavassa tarkastelen yksityiskohtaisemmin yllä selostettuja tutkimuksia ja niitä oletuksia, jotka sinänsä selkeäntuntuisiin tulosten selityksiin kätkeytyvät.

Potilastutkimuksen tulosten tulkinnan lähtökohtana on hyvin karkea malli aivoissa tapahtuvasta tietojenkäsittelystä. Sen ajatellaan tapahtuvan suoraviivaisesti siten, että potilas ottaa passiivisesti vastaan tarjottua ärsykemateriaalia ja tuottaa sen uudelleen jommassa kummassa aivopuoliskossa. Esimerkiksi Sperryn ja Gazzanigan esittämät kuvat potilaiden testaustilanteista ovat usein sellaisia, joissa potilaan edessä näkyy ärsykemateriaalina esitetty kuva ja sama kuva esiintyy myös hänen aivopuoliskossaan.

Psyykkinen toiminta syntyy siis tutkijoiden mielestä toisiaan peräkkäin seuraavien hermostollisten tapahtumien tuloksena ja sen sijaintipaikka on aivoissa. Tästä seuraa suoraan selitys potilaan omituiselle käyttäytymiselle silloin, kun potilaan suullinen raportti on ristiriidassa vasemman käden toiminnan kanssa. Toinen aivopuolisko on vastaanottanut toisen sanan kuin toinen ja koska oletetaan vasemman käden ohjautuvan oikeasta aivopuoliskosta, on tietysti selvää, että se käsi näyttää sen sanan, joka oikealla aivopuoliskolla oli käytettävissään. Tutkijoiden käyttämä selitys osoittaa itse asiassa potilaan toimivan aivan normaalisti; omituinen käyttäytyminen ei enää ole häiriö. Kysymys on ratkaistu, eikä potilaan toimintaa kannata sen enempää tutkia.

On kuitenkin varsin epätodennäköistä, että psyykkinen toiminta olisi tulosta tiedon suoraviivaisesta välittymisestä aivoissa. Psyykkinen toiminta perustuu aivojen kokonaisvaltaisesti järjestäytyneeseen toimintaan; siten sen syntymisen kannalta olennaista ei ole yksittäisen hermosolun tai aivoalueen toiminta, vaan koko aivojen ja hermoston tietynlainen organisaatio. Psyykkinen kuva ei siis synny siten että valoenergia ensin ärsyttäisi verkkokalvon vastaanottimia, sieltä hermoimpulssit etenisivät hermoratoja pitkin aivopuoliskoon, jossa psyykkinen kuva sitten yhtäkkiä välähtäisi. Tämä tutkijoiden perusoletus on aivan ilmeisesti väärä.

Toinen perusoletus oli se, että ärsykemateriaali voidaan todella tarjota siten, että ainoastaan toinen aivopuolisko voisi sen vastaanottaa. Kuten aikaisemmin totesin, commissuurat muodostavat todella ainoan aivopuoliskoja suoraan yhdistävän radan. Aivopuoliskoilla on kuitenkin myös epäsuoria, aivojen syvien osien kautta välittyviä yhteyksiä. Emme tietenkään tiedä, miten näitä yhteyksiä käytetään hyväksi, mutta tutkijoiden esittämä anatomi- nen perustelu voidaan asettaa vähintäänkin kyneenalaiseksi. Varsinkin kun potilailta ei ole katkaistu optista chiasmaa, jonka kautta näköinformaatio yhdestä silmästä välittyy kumpaankin aivopuoliskoon. Emme siis voi olla varmoja siitäkään, onko yhteen näkökentän osaan esitetty informaatio todella vain yhden aivopuoliskon saatavilla.

Kolmanneksi tutkijat olettavat käden toiminnan ohjautuvan yhdestä aivojen osasta, jommasta kummasta aivopuoliskosta. Vasenta kättä kontrolloisi siis oikea aivopuolisko ja oikeaa vasen aivopuolisko. Mutta onko tällekääı oletukselle olemassa selkeitä perusteita? On tietysti yleistä, että oikean aivopuoliskon vauriosta seuraa vasemman kehon puolen halvaus, mutta tästä ei voida vielä vetää sitä johtopäätöstä, että normaalitilanteessa yhden käden toiminnan ohjaus tapahtuisi vain yhdestä aivcpuoliskosta. Aivopuoliskolla on anatomisia yhteyksiä myös saman puolen lihaksistoon. Toisaalta, jos käden toiminnan kontrolli olisi niin voimakkaasti ohjautunut vain yhdestä aivopuoliskosta, miksi sitten useimmat ihmiset käy:tävät oikeata kättään huomattavasti paremmin monissa tehtävissä kuin vasenta? Olisihan tietysti järkevämpää ajatella, että aivopuoliskot olisivat käsien ohjauksessa samanveroisia.

Jos yllä esitetyt kolme oletusta eivät pidäkään paikkaansa potilaan käyttäymisen selittäminen tulee varsin ongelmalliseksi. Jos molemmilla aivopuoliskoilla on käytettävissään suunnilleen sama informaatio ja käsien ohjaus ei ole niin vahvasti ohjautunut vain yhdestä aivopuoliskosta kuin oletetaan, miten sitten selittää potilaan ristiriitainen toiminta?

\section{Vaihtoehtoisia selitys- mahdollisuuksia}

On ensinnäkin todettava, että potilaat, joille commissuuraleikkauksia on suoritettu, ovat säännönmukaisesti potilaita, jotka ovat kärsineet yleensä aiemmista aivovaurioista johtuvasta vakavasta epilepsiasta. Ja ennenkuin leikkaukseen ryhdytään, epilepsia on jatkunut jo useita vuosia tai vuosikymmeniä. Tämä merkitsee sitä, että kaiken kaikkiaan tiedämme hyvin vähän siitä, miten potilaan aivojen organisaatio vastaa aivojen normaalia organisaatiota. Toiseksi leikkaus yleensä vaurioittaa oikean aivopuoliskoa, joka joudutaan vetämään syrjään, jotta aivopuoliskoja yhdistäviin ratoihin päästäisiin käsiksi. Muutkin vauriot ovat mahdollisia, sillä potilaat ovat usein leikkauksen jälkeen mykkiä, heillä on tarkkaavaisuus- 
häiriöitä ja he väsyvät varsin nopeasti. On mahdotonta sanoa liittyvätkö nämä häiriöt commissuurien leikkaukseen, aikaisempiin aivovaurioihin vai leikkauksen tuottamiin muihin aivovaurioihin.

Miksi sitten olettaa, että potilaan ristiriitaiselta näyttävä toiminta leikkauksen jälkeen johtuisi nimenomaan aivopuoliskoja yhdistävien ratojen leikkauksesta? Näyttää siltä, että tutkijoiden usko ennalta asettamiinsa oletuksiin on niin vahva, että vaihtoehtoiset selitykset jätetään yksinkertaisesti huomioimatta.

Mutta voitaisiinko potilaan toimintaa sitten selittää vaihtoehtoisesti? Potilas käyttäytyy selvästi ristiriitaisesti, hän väittää, ettei näe sanaa, jonka kuitenkin toisella kädellään kykenee osoittamaan. Jos potilasta tarkastellaan kokonaisuutena, merkitsee tämä että hän samanaikaisesti tietää, eikä tiedä.

Mutta ovatko tällaiset tilanteet normaali-ihmisilläkään kovin harvinaisia? Muistitoimintojen kohdalla on varsin yleistä, että väitämme tietävämme jonkin asian, jota todellisuudessa emme tiedä. Samoin satamme todeta, että emme tiedä, vaikka meillä onkin jonkinlainen epämääräinen aavistus siitä, että saattaisimme tietää. Voimme myös suorittaa yhden toiminnon kanssa samanaikaisesti muita toimintoja, joista emme ole lainkaan tietoisia. Esimerkiksi lukea ja raapia tukkaa ja kuunnella musiikkia. Itse asiassa on kokeellisia viitteitä siihen suuntaan, että ihmisen kyky suorittaa samanaikaisesti eri tehtäviä ei periaatteessa ole rajallinen.

Saattaisi siis olla, että aivovaurion johdosta kyseisten potilaiden kyky tarkkailla tietoisesti yhtä useampaa sanaa tai näkökentän osaa on heikentynyt, vaikkakin potilas kykenee tiedottomasti osoittamaan, että hän oli perillä muistakin ympäristössä tapahtuvista muutoksista. Tällainen selitys voi hyvinkin olla väärä, eikä auta meitä paljon sen pidemmälle kuin Sperrynkään selitykset, mutta tarkoitukseni on tässä vain korostaa sitä, että potilaan toiminnalle on haettava uusia selityksiä, jos tutkijoiden perusoletukset eivät pidä paikkaansa.

Kuten aikaisemmin totesin, Sperryn kokeista on tehty merkittäviä johtopäätöksiä sen suhteen, kuinka monta persoonallisuutta oikeastaan aivoihin mahtuu. Sperryn mielestä kokeet osoittavat, että persoonia on kaksi. Mutta tämähän on selvä kehäpäätelmä. Ensin oletetaan, että aivopuoliskot ovat tietoisia; tämän oletuksen pohjalta laaditaan sitten koeasetelmä, jonka tuloksista sitten päätellään, että aivopuoliskot ovat tietoisia.

Samaan kehopäätelmään syyllistyy suuri osa asymmetria-tutkimuksia. Oletetaan, että aivopuoliskojen välillä vallitsee toiminnallisia eroja; esitetään ärsykemateriaali siten, että sen kuvitellaan olevan erikseen kummankin aivopuoliskon käytössä ja tuloksista vedetään johtopäätös, että aivopuoliskojen välillä vallitsee toiminnallisia eroja. Mitään muita tulosten selitysvaihtoehtoja ei edes harkita.

Jos potilastutkimusten tulkinnoissa on ollut vaikeuksia, asymmetria-tutkimusten kohdalla ollaan todellisessa suossa. Tutkimuksia on kertynyt valtaisia määriä ja tuloksia on käytetty tukemaan yllä mainittuja aivopuoliskojen psyykkisten toimintojen eroja. Tässä ei ole mahdollista esittää yksityiskohtaisesti tutkimusten kritiikkiä, mutta todettakoon muutama näkökohta.

Jos potilaiden kohdalla on kyseenalaista, saako vain yksi aivopuolisko annetun informaation, normaaleiden henkilöiden kohdalla tämä on täysin kyseenalaista. Aivopuoliskoja yhdistävät radathan ovat tällöin koskemattomat. Kun esimerkiksi kuuloinformaatiota esitetään eri korviin vaikutetaan ilman muuta molempiin aivopuoliskoihin.

Toinen näkökohta koskee käytettyjä ärsykemateriaaleja ja tehtäviä, joiden perusteella toisen aivopuoliskon sanotaan olevan esimerkiksi "'analyyttinen", toisen "kokonaisvaltainen". Vaikka oletettaisiinkin, että informaatio onnistutaan antamaan vain yhteen aivopuoliskoon, tehtävästä suoriutuminen paremmin oikean aivopuoliskon avulla silloin, kun esitetään kuvamateriaalia, ei lainkaan osoita, että oikea aivopuolisko toimisi jotenkin kokonaisvaltaisemmin kuin vasen. Kukaan ei ole osoittanut, että kuvien tarkastelu tapahtuisi jotenkin kokonaisvaltaisemmin kuin esimerkiksi puheen. Kyseessä on jälleen kehäpäätelmä: Kuvien kokonaisvaltainen tarkastelu perustetaan itse asiassa siihen ajatukseen, että oikean aivopuoliskon toimintatapa on kokonaisvaltainen.

Yllä sanottuun liittyy varsin kipeä kohta asymmetria-tutkimuksille. Aivopuoliskoille kyllä annetaan psykologisia ominaisuuksia, mutta todellisuudessa sellaisen ärsykeaineiston tai tehtävien pohjalta, joiden psykologista rakennetta ei itse asiassa ole lainkaan analysoitu. Mihin perustuu esimerkiksi väite, että puhetta käsiteltäisiin sarjallisesti, mutta musiikkia ei? Edellinen käsittelyhän sijoitettiin vasempaan aivopuoliskoon, jälkimmäinen oikeaan. Tai kuinka voimme tietää, ettei käytetyssä ärsykemateriaalissa ole muita eroja kuin oletetut vastakkaisuudet? Esimerkiksi sanan ja kuvan katsotaan erottelevan verbaalisen ja ei-verbaalisen 
välillä, mutta onhan toki visuaalisesti esitettyjen sanojen tai kuvien välillä muitakin eroja, kuin tuo vastakkaisasettelu! Yleensä tutkimuksille on tyypillistä sekä ärsykemateriaalin että tehtävien mielivaltainen valinta.

Asymmetria-tutkimuksen perusongelma on se, että tutkijat uskovat niin vahvasti lähtökohtaolettamuksiinsa, etteivät edes yritä sulkea pois vaihtoehtoisia tulkintoja. Jos ärsykkeitä esitetään vuoroin oikeaan vuoroin vasempaan korvaan ja saadaan aikaan suorituseroja, ensimmäisen kysymyksen tulisi olla: Mistä erot johtuvat? Tutkijalla on kuitenkin vastaus valmiina: Aivopuoliskon erikoistumisesta. Mitä tällöin oikeastaan on selitetty? Ei yhtään mitään, onpahan vain toistettu oletus, josta tutkija lähti liikkeelle. Vaihtoehtoisiakin selityksiä on; oikean korvan rakenne saattaa olla erilainen kuin vasemman, tai koehenkilö on jostain syystä (syystä, jota pitäisi tutkia!) oppinut kiinnittämään enemmän huomiota oikealta tuleviin ääniin. Tutkimustulos osoittaa ensi sijassa sen, että koehenkilön toiminnassa on asymmetrisiä suorituseroja ja tällaisethan ovat yleensä varsin ilmiselviä. Kuitenkin: vaikka koehenkilön toiminta onkin asymmetrista, siitä ei vielä seuraa, että aivotoimintakin olisi sitä.

Palataan vielä lopuksi lyhyesti psyykkisen toiminnan ja aivopuoliskojen väliseen suhteeseen: Onko psyyke aivopuoliskon ominaisuus? Kuten yllä on ehkä tullut selväksi, kysymykseen voidaan vastata painokkaasti EI. Tutkimukset, joilla väittämää on yritetty tukea, ottavat itse asiassa väittämän lähtöoletuksekseen, jolloin tietenkin on selvää, että tulokset tukevat väittämää. Psyykkinen toiminta ei kuitenkaan ole hermosolujen ominaisuus, vaan perustuu päämäärään suuntautuneen organismin koko hermoston organisaatioon.

Psyykkiset ominaisuudet ja toiminnot eivät ole selitettävissä suoraan aivojen anatomisista ja fysiologisista ominaisuuksista. Ihmisen psyyke ei myöskään ole ymmärrettävissä tutkimalla vain erillisten yksilöiden psyykkisiä ominaisuuksia. Psyykkinen toiminta muotoutuu yksilön ja ympäristön välisessä vuorovaikutus- suhteessa, jossa se on ohjaava ja säätelevä tekijä. Ihmisellä tämä vuorovaikutus on kulttuurisesti välittynyttä. Yksilön psyykkiset ominaispiirteet kehittyvät hänen osallistuessaan yhteiskunnan historiallisesti muuttuvaan toimintaan ja omaksuessaan yhteiskunnan kulttuurikehityksen tuottamia henkisen ja käytännöllisen toiminnan välineitä. Vaikka yksilöillä on merkittävä osuus kulttuurisessa kehityksessä, ei kulttuurikehitystä kuitenkaan voida selittää ensisijassa neurofysiologisin tekijöin.

Tieteellisen ihmiskäsityksen kannalta asymmetria-tutkimuksiin sisältyy kaksi virheellistä perlislähtökohtaa. Ihmisen oletetaan ensinnäkin tiedon käsittelyssään olevan passiivinen, mekaanisesti ärsykkeitä käsittelevä päämäärätön olento. Toiseksi alkuperältään yhteiskunnallisia, kulttuurihistoriallisesti määräytyneitä psyykkisiä ominaisuuksia pyritään selittämään fysiologisin tekijöin. Tieteelliseen ihmiskäsitykseen ei voi kuulua sen enempää fysiologisten kuin yhteiskunnallistenkaan tekijöiden käyltö erillisinä selitysperusteina. Ihmisen toiminnassa nämä molemmat tekijät vaikuttavat samanaikaisesti modifioiden toistensa vaikutuksia.

\section{Lähteet}

Martindale, C., Hasenfus, N. and Hines, D. (1976) Hitler: a neurohistorical formulation. Confinia Psychiatrica, 19, 106-116.

Sperry, R. W. (1976) Changing concepts of consciousness and free will. Perspectives in Biology and Medicine, 20, 9-19.

Sperry, R. W., Gazzaniga, M. S. and Bogen, J. E. (1969) Interheminspheric relationships: The neocortical syndromes and hemisphere disconnection. Teoksessa Vinken, P. H. and Bruyn, G. W. (toim.) Handbook of clinical neurology, Vol. 4. Amsterdam: North Holland.

Springer, S. P. and Deutsch, G. (1981) Left brain, right brain. San Francisco: Freeman.

Wigan, A. L. (1844) Duality of the mind. London: Longman, Brown, Green, and Longmans. 